\title{
Et hesteskoformet sår på ryggen
}

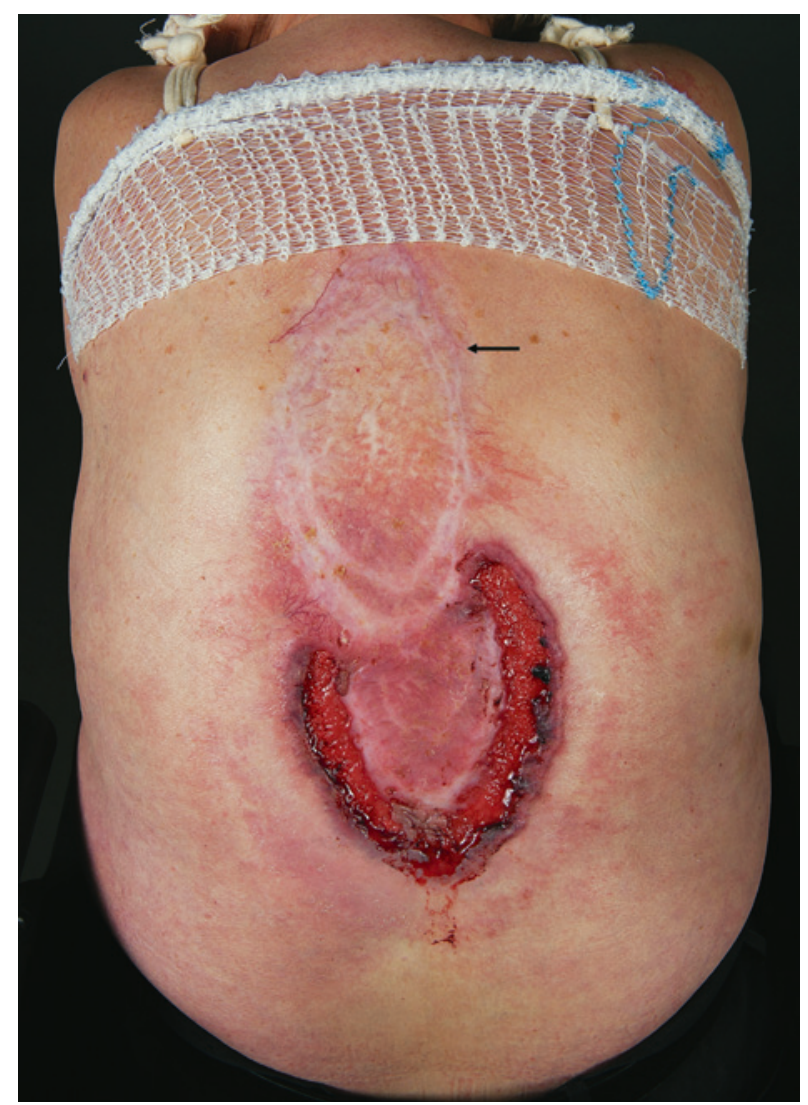

En mann i 80-årene med kols og hypertensjon fikk eksidert et kutant aterom på ryggen. Etter eksisjonen utviklet han et smertefullt ulcus i operasjonssåret. Han ble først behandlet med systemisk antibiotika og antiseptisk lokalbehandling, uten effekt. Diagnosen pyoderma gangrenosum ble så stilt hos lokal hudlege. Behandling med systemisk prednisolon hadde liten effekt, men under infusjonsbehandling med infliximab, en tumornekrosefaktorhemmer, lukket såret seg med arrdanning (pil). Bildet viser et residiv han fikk senere i forløpet, der pasienten fremviste en hesteskoformet ulcerasjon med underminerte sårkanter og en markert inflammatorisk, lilla randsone.

Pyoderma gangrenosum er en inflammatorisk, ikke-infeksiøs hudsykdom som kan ses samtidig med bl.a. inflammatorisk tarmsykdom, revmatoid artritt og - sjeldnere ved myeloproliferative sykdommer (1). Såret kan utvikle seg med utgangspunkt $\mathrm{i}$ et operasjonssnitt eller andre traumer mot huden og vil da kunne oppfattes som en bakteriell sårinfeksjon. Vanligvis trenger pa- sienter med pyoderma gangrenosum systemisk behandling med immunsuppressive legemidler, men lokalbehandling med høypotente steroidpreparater kan av og til være tilstrekkelig. Raskest effekt har prednisolon i høye doser. Ciklosporin kan også ha en frapperende effekt. De siste årene er det kommet mange rapporter om effekt av selektivt immunmodulerende legemidler, såkalte biologiske legemidler, bl.a. tumornekrosefaktorhemmere (1).

Pasienten har gitt samtykke til at artikkelen blir publisert.

\section{Syed Mohammad Husain Rizvi \\ mohammad.rizvi@ous-hf.no \\ Nils-Jørgen Mørk}

Petter Gjersvik

Syed Mohammad Husain Rizvi (f. 1983) er lege i spesialisering ved Seksjon for hudsykdom-

mer, Oslo universitetssykehus, Rikshospitalet.

Forfatter har fylt ut ICMJE-skjemaet og oppgir ingen interessekonflikter.
Nils-Jørgen Mørk (f. 1950) er spesialist i hudog veneriske sykdommer og seksjonsoverlege ved Seksjon for hudsykdommer, Oslo universitetssykehus, Rikshospitalet.

Forfatter har fylt ut ICMJE-skjemaet og oppgir ingen interessekonflikter.

Petter Gjersvik (f. 1952) er spesialist i hudog veneriske sykdommer, dr.med., og førsteamanuensis ved Institutt for klinisk medisin, Universitetet i Oslo.

Forfatter har fylt ut ICMJE-skjemaet og oppgir ingen interessekonflikter.

\section{Litteratur \\ 1. Miller J, Yentzer BA, Clark A et al. Pyoderma gan- grenosum: a review and update on new therapies. J Am Acad Dermatol 2010; 62: 646-54.}

Mottatt 18.6. 2013, første revisjon innsendt 19.9. 2013, godkjent 8.10. 2013. En av forfatterne er redaktør i Tidsskriftet. Manuskriptet er derfor behandlet eksternt av en uavhengig redaktør, Pål Gulbrandsen. 